\title{
Evaluating the Potential Use of Forest Biomass for Renewable Energy: A Case Study with Elements of a Systems Approach
}

\author{
Franciszek Woch ${ }^{1 *}$, Józef Hernik², Edward Sankowski³ ${ }^{3}$ Pawel Pióro ${ }^{4}$, \\ Maria Pazdan', Tomasz Noszczyk ${ }^{2}$ \\ ${ }^{1}$ Department of Soil Science, Erosion and Land Protection, Institute of Soil Science and Plant Cultivation, \\ State Research Institute, Puławy, Poland \\ ${ }^{2}$ Department of Land Management and Landscape Architecture, Faculty of Environmental Engineering \\ and Land Surveying, University of Agriculture in Krakow, Kraków, Poland \\ ${ }^{3}$ Department of Philosophy, College of Arts and Sciences, University of Oklahoma, Norman, Oklahoma, USA \\ ${ }^{4}$ The Jan Kochanowski University in Kielce, Kielce, Poland
}

Received: 7 November 2018

Accepted: 11 December 2018

\begin{abstract}
The aim of this study was to determine the possibility of using residual forest biomass as a renewable energy source based on the analysis and evaluation of production and use. We adopt elements of a systems approach to analyzing and evaluating forest biomass as part of an overall production (and use) process. The area relevant to the research was Ostrowiec Świętokrzyski Forest Inspectorate in Świętokrzyskie Voivodeship, with a total of 17266.32 hectares. The study included areas in both exploitation and pre-exploitation stages, and was based on information from a data management plan for the years 2004-2013 in this inspectorate. The wealth of resources was established and characterized: e.g., the volume of forest stands, the thickness of the timber, expressed in $\mathrm{m}^{3} / \mathrm{ha}$, the annual volume increment, and the average age of forest stands. The estimated realizable amount of woody biomass from forest and wood resources for energy purposes was specified. A logging indicator for economic purposes was set at $70 \%$ growth, and for energy purposes $25 \%$. Waste wood resources (edgings, sawdust, chips, shavings, etc.) were assessed on the basis of logging for industrial purposes, including the rate of $20 \%$ of the initial resources intended for processing. In converting this to an energy value $(18.72 \mathrm{GJ} / \mathrm{t})$ it can be stated that the waste wood from the Ostrowiec Świętokrzyski Forestry Inspectorate can reach 170277 GJ per year. As an intuitive illustration, the resulting volume of energy resources could allow for annual electric lighting for 13844 people or warming 2936 houses. We can generally say that wood waste
\end{abstract}

*e-mail: franciszek.woch@iung.pulawy.pl 
as an energy resource originating in forest districts should meet significant needs for electrical light and heat in an average, typical rural community.

Keywords: forest biomass, renewable energy sources, forest management, biofuels, energy autarky, energy autonomy, Poland

\section{Introduction}

The current exploitation potential for renewable energy sources (RES) is not fully realized in Poland. There is a need to support the production of renewable energy. Development of and use of renewable energy resources has a positive impact on the environment [1, 2], and it may also create local employment growth [3]. However, efficient energy management should provide energy not only for current generations but also for the future [4], and such management should minimize negative impact on the environment $[5,6]$. The increased use of energy from renewable energy sources is also an important part of the potential societal options in the event of failure of what have become traditional energy systems [7]. Supporting the development of RES has become an important policy objective of the European Union [8, 9]. In 1997 a so-called European Commission White Paper was published about a strategy for the development of renewable energy sources in the member states. The importance of renewable energy was reflected there in a limited aspiration, a projected increase in the use of renewable energy in the overall energy mix to $12 \%$ by 2010 [10]. One of the major legal actions in support of RES was the adoption by the European Parliament in 2001 of Directive 2001/77/EC on the promotion of electricity produced from renewable energy sources. In 2008, a new directive was adopted on RES (Directive 2008/28/EC of the European Parliament and of the Council of 11 March 2008 amending Directive 2005/32/EC establishing a framework for the setting of eco-design requirements for energy-using products, as well as Council Directive 92/42/EEC and Directives $96 / 57 / \mathrm{EC}$ and $2000 / 55 / \mathrm{EC}$, as regards the implementing powers conferred on the commission) from a conceptually wider range of potential renewable energy sources. An important objective of the directive is to impose mandatory shares of energy from renewable sources in the overall energy balance consumed by the member states. The overall objective for the European Union is $20 \%$ of energy from renewable sources by 2020 [11]. In 2005 Poland used about 7\% of energy from renewable sources, and in 2020 it intends to use approximately $15 \%[9,12]$. In developing and emerging countries co-integration test results show that there is co-integration between the biomass energy consumption and economic growth [13].

In Poland, at the beginning of the $20^{\text {th }}$ century, when coal was a common source of rural energy, a universal energy source was wood, including forest biomass waste (e.g., branches, wood). In addition, organic wastes from agricultural and animal production could be used as energy sources [14]. Now, with the widespread use in rural households of coal and natural gas, forest residues are used only to a small extent [15]. They remain in the forest, and they can and do enrich the soil with organic matter [16]. In conditions of increasing scarcity of coal, oil, and natural gas reserves, and increasing environmental pollution, it can plausibly be argued that forest "waste" should be used as an energy source. Nevertheless, it can be observed that political incentives are necessary in order to increase the use of forest biomass [11]. Addressing social acceptance will be a prerequisite for the success of initiatives or legislation to achieve this potential $[7,17,18]$.

The aim of this study was to evaluate the possibility of using forest biomass as a renewable energy source based on a thorough analysis of the Ostrowiec Świętokrzyski Forestry Inspectorate. The scope of work included the characterization of raw materials such as wood and waste from the forest for energy production purposes.

In the literature we can encounter many methods for calculating the amount of forest biomass. Ranta [19] noted that researchers started to use GIS for evaluating biomass supply and characteristics. This is of occurrence of dispersed geographical distribution of biomass potential. Padari et al. [20] calculated the amount of forest biomass in Estonia. At an area missing data from the state registry of forest data they created data via modeling using databases and maps (base map, soil map, forest maps). They calculated forest data by soil characteristics. Woodall et al. [21] used to calculate the biomass in the U.S. Forest Inventory by the component radio method (CRM). However, we can't unify research for large areas, because estimates for a tree species in one region may have differed notably from estimates of the same species in another region [20].

In selecting the calculation method, we must take into account the data availability and the specificity of the area. This article focuses on regional studies because of data availability.

\section{Materials and Methods}

\section{Study Area}

Ostrowiec Świętokrzyski Forest Inspectorate was created in 1945 [22]. Currently, the forest area of 17266.32 ha includes Ćmielów forest (6217.62 ha) and Ostrowiec forest (11048.70 ha). The forest resources are located in 1004 complexes in four districts: Ostrowiec, Opatów, Starachowice, and Sandomierz (Fig. 1). 


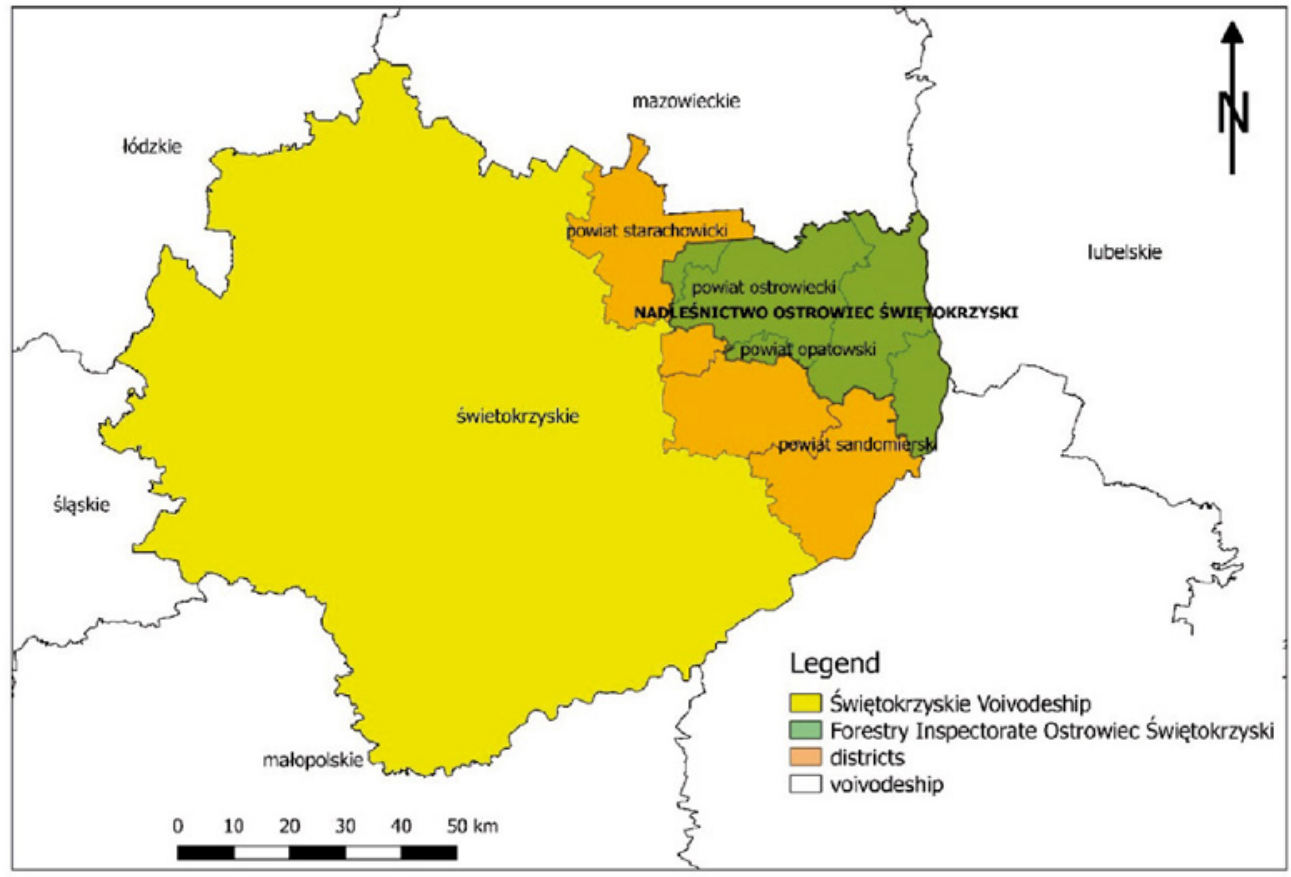

Fig. 1. Location the forest Inspectorate Ostrowiec Świętokrzyski [own execution].

At the Forestry Inspectorate there are 6 partial nature reserves. The area of protected forests is 261.51 ha. It is just $1.5 \%$ of the whole inspectorate area. This information does not significantly affect the calculation and results. Pine is the most common species in this forest, occupying $87.1 \%$ of the forest area. Oak is $7.4 \%$, birch is $2.2 \%$, larch and alder are $0.8 \%$, poplar is $0.6 \%$, the other species (spruce, fir, beech, maple, ash, hornbeam, alder, aspen, linden) occupy only $1.1 \%$ of the forest area [22].

The forest inspectorate for these forests has as its main functions environmental protection and facilitating business. The Forestry Commission has methods of management prescribed under the applicable rules of silviculture [23]. "Special" management and "classic" management are practiced: there are concerns about stroma, pre-stromal phases, and preparation for cutting.

\section{Methods}

Basic methods of harvesting and regeneration of trees contribute to a strategy regulating activities aimed at the gradual change of generations in the forest in a way that ensures the simultaneous removal and replenishment of trees and forests.

The research area covers the entire surface of Ostrowiec Świętokrzyski Forestry Inspectorate. The study covered exploited and pre-exploited areas based on an inventory data management plan for the years 2004-2013, produced by the Ostrowiec Świętokrzyski Forestry Inspectorate [22]. The energy potential of various energy sources was determined on the basis of scientific and expert studies [24]. The first stage of the study was to determine basic characteristics such as the abundance of trees, volume and thickness of wood (thickness of the timber) in the above-ground part of the trees, expressed inm ${ }^{3} \cdot$ ha $^{-1}$ (gross-with bark, net-without bark (Table 3)). In order to determine the size of a timber harvest resulting from financial-economic plans of the inspectorate, we have taken into account the current, annual volume increment and the average age of the trees. Based on data analysis of tree measurement, the estimated realizable amount of wood biomass from the forest has been determined. For the calculation of wood resources by an energy-based method, we have used for our estimate of growth and extraction of timber from the forest the method developed by the European Centre for Renewable Energy using the formula $[25,26]$ :

$$
Z_{D L}=S \cdot C A I\left(F_{w} \cdot F_{e}\right)\left[m^{3} \cdot \text { year }^{-1}\right]
$$

...where:

$Z_{D L}$ - wood from forest for energy purposes $\left[\mathrm{m}^{3} \cdot\right.$ year $\left.^{-1}\right]$ $S$ - forest area [ha],

CAI - current annual increment of volume $\left[\mathrm{m}^{3} \cdot \mathrm{ha}^{-1} \cdot\right.$ year $\left.^{-1}\right]$

$F_{w}$ - logging indicator for economic purposes [\%]

$F_{e}-$ logging rate for energy [\%]

By this calculation, the forest residues (branch, top) and bark are taken into account.

The logging indicator for economic purposes was set at $70 \%$ growth, and the rate of harvesting for energy purposes at $25 \%$ [26], which in state forests is determined based on the percentage of wood assortments used for energy purposes in the overall removals. Assortments included S4 (medium-sized timber), firewood, and M1 and M2 (small timber). 
Table 1. Selected elements of forest stand taxation in the period of the entire existence of the forest stands in the Ostrowiec Świętokrzyski Forestry Inspectorate.

\begin{tabular}{|c|c|c|c|}
\hline \multirow{2}{*}{ Specification } & \multicolumn{2}{|c}{ Forest } & \multirow{2}{*}{ Inspectorate } \\
\cline { 2 - 3 } & Ćmielów & Ostrowiec & 283 \\
\hline The average amount in $\mathrm{m}^{3} \cdot \mathrm{ha}^{-1}$ & 304 & 271 & 361 \\
\hline The average abundance of forests for cutting in $\mathrm{m}^{3} \cdot \mathrm{ha}^{-1}$ & 380 & 351 & 66 \\
\hline The average age of trees in years & 69 & 64 & 4.28 \\
\hline The average increase of trees in $\mathrm{m}^{3} \cdot \mathrm{ha}^{-1}$ & 4.37 & 6.22 & 6.61 \\
\hline The annual growth panel in $\mathrm{m}^{3} \cdot \mathrm{ha}^{-1}$ & 6.58 & 6.64 & 4.96 \\
\hline The annual growth reduced in $\mathrm{m}^{3} \cdot \mathrm{ha}^{-1}$ & 4.93 & 4.98 & \multicolumn{2}{|c|}{4} \\
\hline
\end{tabular}

Source: Ostrowiec Świętokrzyski Forestry Inspectorate data 2015

In order to make the greatest use of the potential of forest biomass available for energy recovery, we also included research on waste wood resources. These resources are assessed based on the size of the timber harvest from national forests, according to the Ostrowiec Świętokrzyski Forestry Inspectorate. It was assumed that wood waste (edgings, sawdust, chips, shavings, etc.) account for approximately $20 \%$ of the initial total intended for processing [27]:

$$
Z_{D T}=P \cdot 0.20\left[\text { tonnes } \cdot \text { year }^{-1}\right]
$$

...where:

$Z_{D T}$ - wood resources from the processing of wood for energy purposes [tonnes $\cdot$ year $^{-1}$ ]

$P$ - timber for industrial purposes [tonnes]

Estimated in this way, resources are converted into units of energy, taking the energy value of dry wood at $18.72 \mathrm{GJ} \cdot \mathrm{t}^{-1}$ [27]. A limitation in using these resources for marketing is that a significant amount of waste generated during the processing of wood by processing industries is consumed for their own use by these plants. However, as waste, sawdust remains after industrial processing but is nevertheless an important raw material used to manufacture fuel pellets [28, 29].

\section{Results and Discussion}

\section{Assessing Biomass Collection for Energy Purposes}

Based on the inventory management plan of the Ostrowiec Świętokrzyski Forestry Inspectorate shown in Table 1, the selected items have been assigned numbers as follows according to characterization of the forest stands.

Wood in the Ostrowiec Świętokrzyski Forestry Inspectorate is being harvested during treatments performed and health checks on younger trees (preexploited) and mature trees (exploited). Comparison of the current array and reduced growth stands contained in Table 1, with cuts designed to reduce the "intensity of care" indicators (gross) in Table 2 shows some notable results. During nursing cuts, mostly in the second (25-30 years) and third (30-50 years) stages of life,

Table 2. Annual increases of pulp of the trees in the examined Inspectorate in the time of the predicted nursing cuts.

\begin{tabular}{|c|c|c|c|}
\hline \multirow{2}{*}{ Specification } & \multicolumn{2}{|c|}{ Trees increase in } & \multirow{2}{*}{ Inspectorate } \\
\hline & Ćmielów & Ostrowiec & \\
\hline \multicolumn{4}{|c|}{ Annual increase in $\mathrm{m}^{3}$ gross $\cdot \mathrm{ha}^{-1}$} \\
\hline Panel & 77.67 & 75.81 & 76.46 \\
\hline Reducted & 58.28 & 56.90 & 57.38 \\
\hline \multicolumn{4}{|c|}{ Annual projected wood harvesting in $\mathrm{m}^{3}$ gross $\cdot$ ha $^{-1}$} \\
\hline Cutting intensity & 38.75 & 37.50 & 37.94 \\
\hline \multicolumn{4}{|c|}{$\%$ of annual harvesting comparing to the annual growth } \\
\hline Panel & 49.90 & 49.46 & 49.62 \\
\hline Reducted & 66.49 & 65.90 & 66.11 \\
\hline
\end{tabular}

Source: Ostrowiec Świętokrzyski Forestry Inspectorate data 2015 
Table 3. Size of annual timber harvest in $\mathrm{m}^{3}$ net in Ostrowiec Forestry Inspectorate.

\begin{tabular}{|c|c|c|c|}
\hline \multirow{2}{*}{ Usage type } & \multicolumn{2}{|c|}{ Forest } & \multirow{2}{*}{ Inspectorate } \\
\cline { 2 - 4 } & Ćmielów & Ostrowiec & 35390 \\
\hline Pre-exploitation use & 12650 & 22740 & 55007 \\
\hline Exploitation use & 19568 & 35439 & 90397 \\
\hline Total & 32218 & 58179 & \\
\hline
\end{tabular}

Source: Ostrowiec Świętokrzyski Forestry Inspectorate data 2015

pulp increase is much greater than the average over the lifetime of the trees.

The amount of planned annual increase of wood in the studied forestry inspectorate is demonstrated in Table 3.

\section{Calculating the Potential of Forest Biomass for Energy Purposes}

Based on the figures in Table 1, reduced annual volume increase $\left(4.96 \mathrm{~m}^{3}\right.$ gross $\left.\cdot \mathrm{ha}^{-1}\right)$ for all districts, and the formula (1) calculating the abundance of wood for energy purposes, we further calculated an estimate of biomass acquired:

$$
\begin{gathered}
Z_{\mathrm{DL}}=17266.32 \mathrm{ha} \cdot 4.96 \mathrm{~m}^{3} \cdot \mathrm{ha}^{-1} \cdot(70 \% \cdot 25 \%) \\
=14987.17 \mathrm{~m}^{3} \cdot \text { year }^{-1}=10491.02 \mathrm{t} \cdot \text { year }^{-1}
\end{gathered}
$$

In a different phase of the systematic exploitation of forests for renewable energy purposes, some waste wood resources are also available for energy from wood processing. On the basis of the figures given in Table 3 (annual exploitation use) and using the appropriate formula (2), we have formulated the following calculation of biomass.

Due to the fact that this forest is almost only one species, we are focusing on one species in the calculation: pine. Assuming that the weight of $1 \mathrm{~m}^{3}$ of solid wood in a condition of air-dry ( $15 \%$ moisture) is about $700 \mathrm{~kg}=0.7 \mathrm{t}$ (indicator for pine as the main species occurring in Polish forests) [25], and assuming the period of one year in which the timber was harvested, we have $\mathrm{P}=55007 \mathrm{~m}^{3} \cdot 0.7 \mathrm{t}=38505 \mathrm{t} \cdot$ year $^{-1}$ and $\mathrm{Z}_{\mathrm{DT}}=38505 \mathrm{t} \cdot 0,20=7701 \mathrm{t} \cdot$ year $^{-1}$.

Using the above calculation, the total amount of forest biomass for energy purposes in the analyzed inspectorate is set as follows:

- The timber resources of the national forests

$-10491 \mathrm{t} \cdot$ year $^{-1}$

- From wood processing $-7701 \mathrm{t} \cdot$ year $^{-1}$

- Total - 18192 tons per year

Considering the energy value of wood at $18.72 \mathrm{GJ} \cdot \mathrm{t}^{-1}$ and moisture content of $50 \%$ during the harvest (for which reason we reduce our calculation by half), the waste wood energy value of the test districts was set at $170277 \mathrm{GJ} \cdot$ year $^{-1}$.
Acquisition of firewood, irrespective of the cut, is almost always in the margins of obtaining the raw material in question, which is of better-quality round wood using conventional methods and technologies. Thus prepared firewood can go directly to the recipient, or be subjected to further processing: cutting to shorter length or in logs and in the form of briquettes or pellets directly useful as energy material [28]. Forestry bulk may also be used to produce biogas [30, 31]. Assuming economic data fuel and energy [26] for electricity consumption in the years 1999 to 2009 , which amounted to an average of $12.3 \mathrm{GJ} \cdot$ person $^{-1} \cdot$ year $^{-1}$ and $58 \mathrm{GJ}$ - annual heat consumption in a house for 3 people, the resulting volume of energy resources will supply energy for annual lighting for 13844 people or warmth for 2936 houses. The average community has less than half of this population and about half are in single-family homes. Therefore one can generally say that waste energy resources from analyzed forest districts should meet the needs of electrical light and heating for many rural communities.

Forest resources in the relevant Inspectorate are 17266.32 hectares. This is an area corresponding to the surface of two smaller municipalities in Poland. From this, one can generally say that utilizing the forest area corresponding to the surface of the average municipality (8-10 thousand hectares), we can meet central energy needs of society for half of the municipality or supply energy self-sufficiency areas with low population density. We may also reasonably state that the use of residual forest biomass is a very real possible resource [32], but requires the introduction of favorable economic and organizational rules, the use of appropriate technology, e.g., technology for processing [33] and stabilization of the quality of the biomass [34]. The use of biomass does not cause noteworthy additional emissions [11], promotes the development of local labour markets [32], and can provide adequately for energy self-sufficiency areas with low population density [15]. Also, the replacement of coal by biomass in individual farms will reduce the so-called "low emission" of noxious pollutants (reducing emissions of particulates, polycyclic aromatic hydrocarbons (PAHs), nitrogen oxides and sulfur oxides) [21]. Furthermore, increasing the use of biomass can help reduce greenhouse gas emissions [35], diversify energy supply, and create growth and jobs [36]. 
To sum up, optimal energy, environmental and economic use of forest biomass extracted from Ostrowiec Świętokrzyski Forestry Inspectorate is realistic, but the conditional use of appropriate technology and biomass processing technology is crucial, and the provision and quality of biomass stabilization is also required [22]. Moreover, all decision-making agents and institutions engaged in the forest economy should cooperate with each other. The development of forest bioenergy requires increased cooperation between the government and enterprises with respect to the different functions of the forest and its impact on the ecosystem [37]. This case study points to the need for "complex systems" analysis and design, and it provides some critical elements necessary for a more comprehensive such analysis and design. Design of complex systems for forestry management and related energy production, as well as use of renewable energy from forest biomass, is a promising approach for Poland. This would require the integration of information for decision-making from many sources, which might be enhanced by what has come to be called "the internet of things". Increasing computerization of the data provided in this study, and further types of data, will be needed. Exploring that more fully is already necessary, and more sophisticated computation is coming in the near future, but that topic, while an extension of the present inquiry, is beyond the scope of this paper.

\section{Conclusions}

Summarizing the results of the study, we can generally state:

1. In the area of the Ostrowiec Świętokrzyski Forestry Inspectorate there is a lot of forest biomass, which is possible to acquire and process for the purpose of clean energy, which to some extent could contribute to reducing the amount and cost of the annual consumption of non-renewable energy sources. It is possible to obtain an annual 18192 tons of biomass from forest residues, including 10491 tons of wood resources from forests and 7701 tons of wood processing. The energy value of wood from a forest inspectorate test was estimated at $170277 \mathrm{GJ} /$ year.

2 . The resulting volume of energy resources will allow for annual lighting for 13844 people or could keep 2936 houses warm. One can generally say that waste energy resources of the analyzed forest inspectorate should meet the needs for electricity and heating of many typical rural communities.

3. Given the forest area corresponding to the surface of the average rural commune (8-10 thousand hectares), we can meet the central energy needs of society for half of the municipality or provide for energy self-sufficiency areas with low population density.

4. The use of forest biomass does not cause noteworthy additional emissions and promotes the development of local labor markets. This assumes processing of forest biomass for use that is consistent with public health standards, a point about which there is optimism expressed by some reasonably reliable and authoritative sources such as the U.S. Environmental Protection Agency.

5. The use of forest biomass, extracted from the test districts, has very real potential, but requires the use of appropriate technology, including basic biomass processing technology, and technology for assuring the provision and quality of biomass stabilization.

\section{Acknowledgements}

This research was financed by the Ministry of Science and Higher Education of the Republic of Poland (project No. DS 3371/KGPiAK/2018).

\section{Conflict of Interest}

The authors declare no conflict of interest.

\section{References}

1. SLIZ-SZKLINIARZ B. Assessment of the renewable energy-mix and land use trade-off at a regional level: A case study for the Kujawsko-Pomorskie Voivodship. Land Use Policy, 35, 257, 2013.

2. KAZAK J., DZIEZYC H., FORYS I., SZEWRAŃSKI S. Indicator-based analysis of socially sensitive and territorially sustainable development in relation to household energy consumption. In Proceedings of $17^{\text {th }}$ International Scientific Conference: Engineering for Rural Development, Jelgava, Latvia; 1653, 2018.

3. GAWROŃSKA G., GAWROŃSKI K. The method of assessment of potential ecological effects of obtaining energy from the straw biomass. Acta Scientiarum Polonorum-Formatio Circumiectus, 15, 69, 2016.

4. SANKOWSKI E., HARRIS B.J., HERNIK J. Some problems and possibilities for sustainable development. Publishing House of the University of Agriculture in Krakow: Kraków, 2016.

5. RODRIGUES E., GOMES A., GASPAR A.R., ANTUNES C.H. Estimation of renewable energy and built environment-related variables using neural networks - A review. Renewable \& Sustainable Energy Reviews, 94, 959, 2018

6. MROWCZYŃSKA M., LACZAK A., BAZAN-KRZYWOSZANSKA A., SKIBA M. Improving Energy Efficiency with the Risk of Investment of Reference to Urban Development of Zielona Gora. Tehnicki Vjesnik-Technical Gazette, 25, 916, 2018.

7. MRÓWCZYŃSKA M., SKIBA M., BAZAN-KRZYWOSZAŃSKA A., BAZUŃ D., KWIATKOWSKI M. Social and infrastructural conditioning of lowering energy costs and improving the energy efficiency of buildings in the context of the local energy policy. Energies, 11 (9), 2302, 2018.

8. KNOPF B., NAHMMACHER P., SCHMID E. The European renewable energy target for 2030 - An impact assessment of the electricity sector. Energy Policy, 85, 50, 2015. 
9. HERNIK J., RUTKOWSKA A., NOSZCZYK T. Correlation between selected socioeconomic variables and the number of renewable energy sources in Świętokrzyskie Voivodeship (Poland). In $15^{\text {th }}$ International Scientific Conference: Engineering for Rural Development, Latvia Univ Agriculture: Jelgava, 15, 498, 2016.

10. ABBASPOUR M., KARBASSI A., ASADI M.K., MOHARAMNEJAD N., KHADIVI S., MORADI M.A. Energy Demand Model of the Household Sector and Its Application in Developing Metropolitan Cities (Case Study: Tehran). Polish Journal of Environmental Studies, 22, 319, 2013.

11. PASCHALIS-JAKUBOWICZ P. Forest biomass as a renewable energy source - consequences for forestry. Sylwan, 162, 688, 2018.

12. WOCH F., HERNIK J., WYROZUMSKA P., CZESAK B. Residual Woody Waste Biomass as an Energy Source - Case Study. Polish Journal of Environmental Studies, 24, 355, 2015.

13. BILDIRICI M.E. Economic growth and biomass energy. Biomass \& Bioenergy, 50, 19, 2013.

14. NAWALANY G.,BIEDA W.,RADON J.,HERBUT P. Experimental study on development of thermal conditions in ground beneath a greenhouse. Energy and Buildings, 69, 103, 2014.

15. WOCH F., HERNIK J., WIKLINA U., TOLAK M. Energy Autarky of Rural Municipality Created on the Basis of Renewable Energy Resources. Polish Journal of Environmental Studies, 23, 1441, 2014.

16. ZHANG H., WANG K.L., ZENG Z.X., ZOU Z.G., XU Y.F., ZENG F.P. Multiple Factors Drive Variation of Forest Root Biomass in Southwestern China. Forests, 9, 456, 2018.

17. ROTHE A., MORONI M., NEYLAND M., WILNHAMMER M. Current and potential use of forest biomass for energy in Tasmania. Biomass \& Bioenergy, 80, 162, 2015.

18. KARYTSAS S., THEODOROPOULOU H. Socioeconomic and demographic factors that influence publics' awareness on the different forms of renewable energy sources. Renewable Energy, 71, 480, 2014.

19. RANTA T. Logging residues from regeneration feelings for biofuel production - a GIS-based availability analysis in Finland. Biomass and Bioenergy, 28 (2), 171, 2005.

20. PADARI A., MUISTE P., MITT R., PÄRN L. Estimation of Estonian wood fuel recources. Baltic Forestry, 15 (1), 77, 2009.

21. WOODALL C.W., HEATH L.S., DOMKE G.M., NICHOLS M.C. Methods and equations for estimating aboveground volume, biomass, and carbon for trees in the U.S. forest inventory, 2010. Final Report. Newtown Square, PA, 30, 2011.

22. Ostrowiec Forest Division Forest Management Plan for Ostrowiec Świętokrzyski Forest Division for 2004-2013. 2013.

23. Serwis internetowy Lasów Państwowych. Availabe online: www.lasy.gov.pl (accessed on 1 August 2018).
24. LARSSON S., NILSSON C. A remote sensing methodology to assess the costs of preparing abandoned farmland for energy crop cultivation in northern Sweden. Biomass \& Bioenergy, 28, 1, 2005.

25. BUCZEK J., KRYŃSKA B., TOBIASZ-SALACH R. The evaluation of woody biomass for energetic purposes in Podkarpackie Voivodeship. In Innowacje w technologiach roślinnych podstawą kształtowania rolniczej przestrzeni produkcyjnej przez samorząd terytorialny, Wydawnictwo Uniwersytetu Rzeszowskiego: Rzeszów, 132, 2008.

26. EEC. The demand for biomass for energy purposes in Poland for the years 2006 to 2014. European Centre for Renewable Energy: Warsaw, 2006.

27. KOWALCZYK-JUŚKO A. Regional Biomass Resources for Energy Purposes (Methodical Problems). Annals of Warsaw Agricultural University SGGW, 85, 103, 2010.

28. PRADHAN P., ARORA A., MAHAJANI S.M. Pilot scale evaluation of fuel pellets production from garden waste biomass. Energy for Sustainable Development, 43, 1, 2018.

29. SCHLESINGER W.H. Are wood pellets a green fuel? Science, 359, 1328, 2018.

30. AGARWALA M., GHOSHAL S., VERCHOT L., MARTIUS C., AHUJA R., DEFRIES R. Impact of biogas interventions on forest biomass and regeneration in southern India. Global Ecology and Conservation, 11, 213, 2017.

31. NOSZCZYK T., HERNIK J., CHABA D. Potential Production of Bioethanol in the Swietokrzyskie Voivodeship (Poland). In Energy and Clean Technologies Conference Proceedings, SGEM 2016, Stef 92 Technology Ltd: Sofia, I, 549, 2016.

32. BEETON T.A., GALVIN K.A. Wood-based bioenergy in western Montana: the importance of understanding path dependence and local context for resilience. Ecology and Society, 22 (2), 9, 2017.

33. PRIETO M.G., SANCHEZ F.A., PEREDA S. Thermodynamic model for biomass processing in pressure intensified technologies. Journal of Supercritical Fluids, 96, 53, 2015.

34. PERKINS G., BHASKAR T., KONAROVA M. Process development status of fast pyrolysis technologies for the manufacture of renewable transport fuels from biomass. Renewable \& Sustainable Energy Reviews, 90, 292, 2018.

35. PAOLOTTI L., MARTINO G., MARCHINI A., BOGGIA A. Economic and environmental assessment of agro-energy wood biomass supply chains. Biomass \& Bioenergy, 97, 172, 2017.

36. VACCHIANO G., BERRETTI R., MOTTA R., MONDINO E.B. Assessing the availability of forest biomass for bioenergy by publicly available satellite imagery. Iforest- Biogeosciences and Forestry, 11, 459, 2018.

37. QU M., AHPONEN P., TAHVANAINEN L., GRITTEN D., MOLA-YUDEGO B., PELKONEN P. Practices and perceptions on the development of forest bioenergy in China from participants in national forestry training courses. Biomass \& Bioenergy, 40, 53, 2012. 
